\title{
A survey of the bacterial composition of kurut from Tibet using a culture-independent approach
}

\author{
W. J. Liu, ${ }^{* 1}$ Z. H. Sun, ${ }^{\star 1}$ Y. B. Zhang, ${ }^{\star}$ C. L. Zhang, ${ }^{*}$ Menghebilige, ${ }^{*}$ M. Yang, ${ }^{*}$ T. S. Sun, ${ }^{*}$ Q. H. Bao, ${ }^{*}$ W. Chen, $\dagger^{2}$ \\ and H. P. Zhang ${ }^{\star 2}$ \\ *Key Laboratory of Dairy Biotechnology and Engineering, Ministry of Education, Inner Mongolia Agricultural University, Huhhot, \\ Inner Mongolia, P. R. China, 010018 \\ †School of Food Science and Technology, Jiangnan University, Wuxi, Jiangsu, P. R. China, 214122
}

\section{ABSTRACT}

Kurut (fermented yak milk) made by natural fermentation is a very important dairy food for the local people in Tibet (China). It is important to fully understand the bacterial composition of kurut for quality improvement and industrial production. Because more than $99 \%$ of prokaryotes cannot be cultured and identified by methods currently used in taxonomy, we applied a culture-independent approach to explore the microbial biodiversity of this traditional food. In this study, a bacterial 16S rRNA gene clone library, including 460 clones, was constructed using total DNA extracted from 30 samples of kurut. After screening by restriction fragment length polymorphism (RFLP) analysis, 56 operational taxonomic units (OTU) with unique RFLP patterns were obtained. Then, 1 representative sequence of every OTU was sequenced and phylogenetically analyzed. The representative phylotypes were affiliated with 5 groups, including Lactococcus lactis ssp. lactis, Lactobacillus helveticus, Streptococcus thermophilus, Lactobacillus delbrueckii ssp. bulgaricus, and Acetobacter. In addition, nearly one-third of the representative clones (132 clones) had low similarity to species in GenBank $(<97 \%)$, and these phylotypes were regarded as unknown bacteria. The characteristics of kurut are determined not only by lactic acid bacteria well known by the culture-dependent approach but also by bacteria that have not yet been identified.

Key words: kurut, 16S rRNA gene clone library, restriction fragment length polymorphism, bacterial biodiversity

\footnotetext{
Received December 21, 2010.

Accepted November 10, 2011

${ }^{1}$ Wenjun Liu and Zhihong Sun contributed equally to this paper.

${ }^{2}$ Corresponding authors: weichen@jiangnan.edu.cn and hepingdd@ vip.sina.com
}

\section{INTRODUCTION}

Kurut (fermented yak milk) is a naturally fermented dairy product and a main source of livelihood for Tibetan households in the Qing-Tibetan highlands. It has long played important economic and dietary roles to the people of Qinghai and Tibet (Cao et al., 2004). Kurut is a pure white, viscous, fermented dairy food with unique organoleptic sensations of acidity and alcohol; fermentation usually takes 3 to $6 \mathrm{~d}$ at an ambient temperature around 10 to $20^{\circ} \mathrm{C}$ to achieve the desired properties. Kurut contains $5.37 \%$ milk fat and approximately $5.44 \%$ total protein, on average, which is about twice as rich in fat and protein as in yogurt. The contents of calcium (140 mg/100 g), phosphorus (146 mg/100 g), magnesium (154 mg/100 g), zinc (5.74 $\mathrm{mg} / 100 \mathrm{~g}$ ), and B vitamin in kurut are also higher than in yogurt (Zhang et al., 2008). Because of the desirable nutritious and organoleptic properties of kurut, it is important to fully understand its microbiological composition for the design of starter cultures and industrial production.

Microorganisms such as lactic acid bacteria (LAB) and yeast play key roles during the making of kurut, and Lactobacillus delbrueckii ssp. bulgaricus and Streptococcus thermophilus are the predominant populations in kurut (Zhang et al., 2008; Sun et al., 2010). However, knowledge concerning the microflora of dairy products often comes from traditional culture-dependent methods. These methods can give significant insights into specific isolates and microbial populations in different environments, but the culture media used may not be sufficiently selective for monitoring population dynamics and may fail to recover unculturable bacteria, resulting in an underestimation of microbial diversity. Generally, more than $99 \%$ of prokaryotes cannot be cultured using traditional methods (Amann et al., 1990; Schloss and Handelsman, 2005). In addition, the traditional classification is time-consuming and lacks wide coverage needed to analyze temporal variations in complex bacterial communities in natural food ecosystems (Yanagida et al., 2007; Scheirlinck.et al., 2008) 
Novel molecular approaches, especially those based on the utilization of rRNA genes, have provided us with the opportunity to analyze complex communities based on sequence diversity (Amann et al., 1995). In particular, metagenomics was coined as a new and rapidly developing field in the analysis of microbial community about 10 yr ago (Handelsman et al., 1998), and this culture-independent method has opened up fresh perspectives in microbiology (Hugenholtz and Tyson, 2008).

In recent studies, both culture-dependent and culture-independent methods were applied to the analysis of microbial biodiversity and ecology in different environments (Pidiyar et al., 2004; Obodai and Dodd, 2006; Chen et al., 2008). In the food research field, Aquilanti et al. (2007) showed that the microbial diversity of fermented meat products could be successfully investigated by culture-dependent and culture-independent approaches. This reliable and rapid approach was also used to study the composition of LAB in probiotic products (Temmerman et al., 2003) and in cheese (Randazzo et al., 2002). However, we know of no research on the analysis of the bacterial composition of kurut in Tibet using culture-independent methods.

Therefore, we intended to investigate the bacterial composition of kurut using a culture-independent approach, which will be useful in future studies to improve the quality and optimize the manufacturing process of kurut. In this study, a bacterial 16S rRNA gene clone library containing 460 clones was constructed and the bacterial diversity in kurut was systematically studied.

\section{MATERIALS AND METHODS}

\section{Sample Collection}

Thirty kurut samples were collected from 16 villages located in 3 regions of Tibet during the period from July 25 to August 10, 2007. Samples were aseptically collected and kept in ice boxes during transportation. Once the samples arrived at the laboratory, they were immediately analyzed for microbial composition.

\section{Extraction of Bacterial DNA}

Bacterial DNA extraction was carried out with some modifications to the protocol of Lick et al. (1996). In brief, $1 \mathrm{~mL}$ of sample was frozen in liquid nitrogen for 5 min and thawed in a water bath at $60^{\circ} \mathrm{C}$. Then, $600 \mu \mathrm{L}$ of freshly prepared $400 \mathrm{mmol} / \mathrm{L} \mathrm{NaOH}$ and $300 \mu \mathrm{L}$ of $40 \%$ (wt/vol) trisodium citrate dihydrate (wash buffer A) were added to the thawed sample. After mixing, the sample was incubated for $15 \mathrm{~min}$ at room temperature and then centrifuged for $4 \mathrm{~min}$ at $10,000 \times g$. The su- pernatant fluid containing the fat layer was discarded. This step (addition of wash buffer A) was repeated twice. After that, the sediment was dissolved in sterile ultrapure water. Then, $50 \mu \mathrm{L}$ of $10 \%$ SDS and $10 \mu \mathrm{L}$ of proteinase $\mathrm{K}$ solution $(10 \mathrm{mg} / \mathrm{mL}$ ) were added, and the mixture was incubated at $55^{\circ} \mathrm{C}$ for $1 \mathrm{~h}$. At the end of the incubation, $10 \mu \mathrm{L}$ of $\mathrm{NaCl}(5 M)$ and $100 \mu \mathrm{L}$ of cetyltriethylammnonium bromide/ $\mathrm{NaCl}(10 \%$, wt/wt) were added, followed by incubation for $10 \mathrm{~min}$ at $65^{\circ} \mathrm{C}$. Deproteinization was conducted by extraction with 1 volume of phenol-chloroform-isoamyl alcohol (25:24:1) and chloroform-isoamyl alcohol (24:1) twice. Finally, DNA was precipitated by adding 0.1 volume of $3 M$ sodium acetate to the water phase followed by 1 volume of icecold isopropyl alcohol. The DNA was collected, washed, and dissolved in $50 \mu \mathrm{L}$ of sterile ultrapure water.

\section{S rRNA Amplification by PCR}

Amplification of the bacterial 16S rRNA gene was carried out on an automatic thermal cycler (MJ Research PTC-200, Bio-Rad, Hercules, CA) using the universal primers of 16S rRNA gene (Lane, 1991; Delbes et al., 2007); the primer sequences were (27f) 5'-AGAGTTTGATCCTGGCTCAG-3' and (1495r) 5'-CTACGGCTACCTTGTTACGA-3'. The PCR reaction mixture was prepared according to the protocol of Wang et al. (2008). Each sample contained $1 \times$ Taq buffer (Takara Bio-Company, Shiga, Japan), $1.5 \mathrm{mM} \mathrm{MgCl} 2,0.2$ $\mathrm{mmol} / \mathrm{L}$ of each dNTP, $0.2 \mu \mathrm{M}$ of each primer, $50 \mathrm{ng}$ of template bacterial DNA, 1.0 U of Ex Taq polymerase (Takara Bio-Company), and $50 \mu \mathrm{L}$ of deionized water. The PCR amplification procedure was as follows: $94^{\circ} \mathrm{C}$ for $5 \mathrm{~min}, 31 \mathrm{cycles}$ at $94^{\circ} \mathrm{C}$ for $1 \mathrm{~min}, 58^{\circ} \mathrm{C}$ for $1 \mathrm{~min}$, $72^{\circ} \mathrm{C}$ for $2 \mathrm{~min}$, and then $72^{\circ} \mathrm{C}$ for $8 \mathrm{~min}$, and finally $4^{\circ} \mathrm{C}$ for $30 \mathrm{~min}$. The approximately 1,450-bp PCR products were obtained from each sample of total DNA, which was tested by $1 \%$ agarose gel electrophoresis.

\section{Construction of 16S rRNA Clone Library}

The PCR products were purified by DNA purification kit (Takara Bio-Company), and these PCR products were inserted into PMD18-T vector (Takara Bio-Company) between BamHI and HindIII sites. The recombinant plasmid was transformed into Escherichia coli $\mathrm{DH} 5 \alpha$ and induced with $1 \mathrm{mmol} / \mathrm{L}$ isopropy- $\beta$-Dthiogalactoside. Recombinant plasmid was confirmed by restriction enzyme digestion and PCR amplification. Randomly selected positive colonies were used to construct 16S rRNA gene clone libraries. The purified product of PCR was linked to PMD18-T vector following the instructions in the vector kit. Briefly, the total $10-\mu \mathrm{L}$ reaction system consisting of $4 \mu \mathrm{L}$ of products 
of PCR, $1 \mu \mathrm{L}$ of PMD18-T, and $5 \mu \mathrm{L}$ of solution I was incubated for $10 \mathrm{~h}$ at $16^{\circ} \mathrm{C}$. Then, the recombinant plasmid was transformed into E. coli strain $\mathrm{DH} 5 \alpha$ by heat-shock transformation (Sambrook et al., 2002). The plates were incubated overnight (for 12 to $16 \mathrm{~h}$ ) at $37^{\circ} \mathrm{C}$. $\beta$-Galactosidase-positive white colonies were analyzed by restriction enzyme digestion. Subsequently, 460 transformants with the proper inserts confirmed by PCR were used to construct the metagenomic library.

\section{Scanning of $16 S$ rRNA Library by RFLP}

Screening of this library was carried out according to the methods described by Sato et al. (2000) and Weidler et al. (2007) with some modifications. The DNA of recombinant plasmid was extracted by plasmid mini preparation kit (Takara). The 16S rRNA gene fragment of each clone was amplified using the universal primers $27 \mathrm{f}$ and $1495 \mathrm{r}$. Five microliters of each PCR amplified product was digested with the restriction endonucleases AluI, HaeIII and HinfI (Boehringer Mannheim, Mannheim, Germany) as recommended by the manufacturer. The RFLP profiles were analyzed, and all the clones were divided into different groups (operational taxonomic units, OTU) according to RFLP profiles, which represented the different bacterial phylotypes in kurut.

\section{Sequencing of Library Clones}

Partial 16S rRNA gene (approximately 1,400 bp for each representative OTU) was sequenced on ABI Prism 3730XL DNA Analyzer (Sunny Biotechnology Co. Ltd., Shanghai, China). All the sequences were assembled using DNAstar software package (1989, DNAStar Inc., Madison, WI).

The determined $16 \mathrm{~S}$ rRNA gene sequences were aligned and the phylogenetic tree was constructed by the neighbor-joining method using MEGA software version 4.0 (Kumar et al., 2004). The representative sequences of every species were selected from isolates for phylogenetic tree construction. The species identification of phylotypes was confirmed by comparing the sequences of OTU with the type strains using the phylogenetic tree. The sequences were analyzed and determined through BLAST search on the National Center for Biotechnology Information website (http:// blast.ncbi.nlm.nih.gov/Blast.cgi). The sequences obtained in this study for all phylotypes were deposited in GenBank.

\section{Analysis of Data}

The diversity coverage of the clone library was estimated by rarefaction analysis with Analytical Rarefac- tion software version 1.3 (S. M. Holland, University of Georgia, Athens; http://www.uga.edu/strata/software. html). The diversity and species richness were analyzed by the Species Prediction and Diversity Estimation software (SPADE; Chao and Shen, 2003).

\section{RESULTS AND DISCUSSION}

Within the complex bacterial community of traditional fermented dairy products, LAB are considered to be the dominant microflora, and the variety of $\mathrm{LAB}$ in fermented dairy products depends on the starter culture used and the raw milk. Traditional research on the microflora of dairy products relies heavily on pure culture isolation, suitable substrates, and culture media. However, cultivable microorganisms are not always representative of the microflora in a complex ecosystem. It has been reported that only a small fraction of microorganisms are obtained by conventional methods (Ward et al., 1990; Engelen et al, 1998). In contrast, culture-independent methods can provide a more realistic view of the microbial diversity in the ecosystem, as demonstrated in Mozzarella cheese (Coppola et al., 2001) and typical Italian salami (Aquilanti et al., 2007).

To clarify the microbial diversity in the traditional kurut in Tibet, we constructed a bacterial 16S rRNA gene clone library. The microbial diversity and species richness were studied by RFLP and sequences analysis.

\section{Analysis of 16S rRNA Gene Clone Library}

A bacterial 16S rRNA gene clone library containing 460 clones was successfully constructed with total DNA extracted from the kurut samples, and the rarefaction analysis revealed that the clone library was sufficient to cover the bacterial diversity (Figure 1 and Table 1). The coverage rate of the library was $92.1 \%$, Shannon index was 5.4, and Simpson index was 0.1. According to the report by Kemp and Aller (2004), the size of this $16 \mathrm{~S}$ rRNA gene clone library was sufficient for the analysis of microbial diversity.

The phylotype diversity analysis was conducted by scanning the clone library using RFLP and sequences analysis, and 56 phylotypes were identified based on the RFLP profiles. Then, each phylotype was confirmed by $16 \mathrm{~S}$ rRNA sequence analysis. Partial sequences of the $16 \mathrm{~S}$ rRNA gene $(1.4 \mathrm{~kb})$ of all the representative clones with unique RFLP patterns were sequenced and phylogeneticlly analyzed. All of the representative sequences in the present study were deposited in GenBank with accession numbers GQ267858 to GQ267992.

Based on the BLAST search results, the sequences were classified into 2 parts. Part 1 contained 5 OTU 
Table 1. Diversity estimate of $16 \mathrm{~S}$ rRNA clone library by SPADE software (Chao and Shen, 2003) ${ }^{1}$

\begin{tabular}{|c|c|c|c|c|c|c|c|}
\hline \multirow[b]{2}{*}{ No. of OTU } & \multirow[b]{2}{*}{$\mathrm{C}$} & \multicolumn{2}{|c|}{ Species richness } & \multicolumn{2}{|c|}{ Shannon index } & \multicolumn{2}{|c|}{ Simpson index } \\
\hline & & FSR & $95 \% \mathrm{CI}$ & $\begin{array}{c}\text { Chao and } \\
\text { Shen (2003) }\end{array}$ & $95 \% \mathrm{CI}$ & MLE & $95 \% \mathrm{CI}$ \\
\hline 55 & 92.1 & 34.5 & $(81.8,229.2)$ & 5.4 & $(61.3,84.1)$ & 0.1 & $(56.0,56.7)$ \\
\hline
\end{tabular}

(OTU 1 to 5$)$ that exhibited high similarity (>97\%) to the type strains or identified species in GenBank. Part 1 was the major component of the $16 \mathrm{~S}$ rRNA gene clone library, occupying about $70.5 \%$ of the total clones. Part 2 was composed of 51 OTU, including 132 clones in the library with low phylogenetic similarity $(<97 \%)$ to the identified species (Table 2). To identify these species, phylogenetic analysis was conducted. Some sequences of type strains and representative sequence of each clone were used to construct a phylogenetic tree.

\section{Identification of Phylotypes with High Phylogenetic Similarity}

In the $16 \mathrm{~S}$ rRNA gene clone library, part 1 included major sequences that could be identified by BLAST search, and the sequences in this part were resolved to 5 OTU. Among them, OTU 1 was the largest group, containing 155 clones, and was identified as Lactobacillus helveticus with 97 to $100 \%$ similarity to the type strains or identified species in GenBank by BLAST search. The second group, comprising $15.6 \%$ of the total clones, was identified as Lb. delbrueckii ssp. bulgaricus, with 97 to $100 \%$ similarity. The third group, which contained 58 clones ( $12.4 \%$ of total clones), was

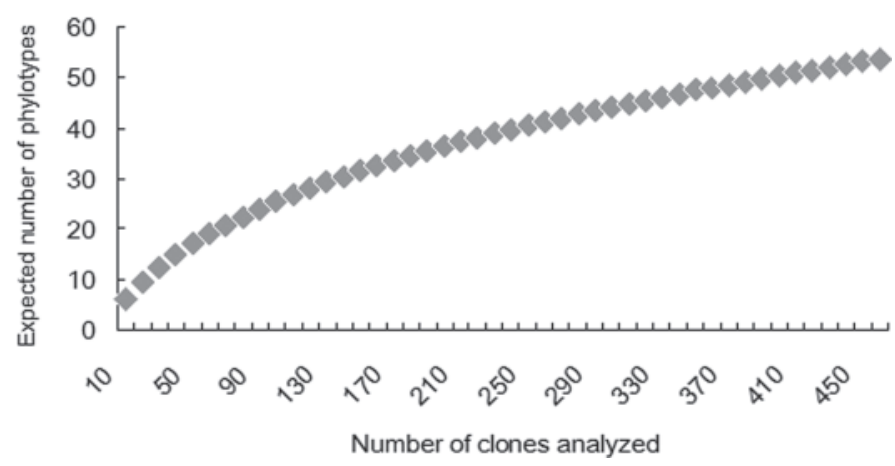

Figure 1. Rarefaction curve for bacterial compositon of kurut samples. The $\mathrm{x}$-axis represents the numbers of the total samples of $16 \mathrm{~S}$ sRNA gene clones, and the $y$-axis represents operational taxonomic units (OTU) clustered by $16 \mathrm{~S}$ rRNA gene clones. We showed that OTU were close to their saturation curve and that the clone library was sufficient to cover the bacterial diversity. assigned to Streptococcus thermophilus with similarity of $100 \%$ to the identified sequences in GenBank. The remaining 29 clones were regarded as Lactococcus lactis ssp. lactis, with $99 \%$ similarity.

Twenty sequences with high similarity $(>97 \%)$ to the identified species in GenBank or type strains were used to construct the phylogenetic tree (Figure 2). These phylotypes were classified into 6 clusters. Cluster I contained 7 sequences identified as $L b$. delbrueckii ssp. bulgaricus with 97 to $100 \%$ similarity. Cluster II (including 4 sequences) was identified as the $L b$. helveticus group with 97 to $100 \%$ similarity to the type strain of Lb. helveticus in GenBank. Cluster III was Lc. lactis ssp. cremoris, including 2 sequences with 97 to $99.8 \%$ similarity to the type strain in GenBank, and cluster IV was Strep. thermophilus with $100 \%$ similarity to the 2 sequences listed in the GenBank. The remaining phylotypes with high similarity to the species in GenBank were the Pseudomonas group (cluster V) containing 2 sequences and the Acetobacter group (cluster VI) including 3 sequences.

Part 1 was the major segment in the library, including 328 clones representing $71.2 \%$ of the total clones in the bacterial $16 \mathrm{~S}$ rRNA gene clone library. Our results indicated that $L b$. delbrueckii ssp. bulgaricus, Lb. helveticus, Lactococcus lactis, and Strep. thermophilus were the major microbial flora in kurut from Tibet. This result was in agreement with the previous study, which found that Lb. delbrueckii ssp. bulgaricus and Strep. thermophilus were the predominant species in kurut from Qinghai (Sun et al., 2010). However, different results were reported in a previous study described by Yu et al. (2009), which found the presence of Lactobacillus fermentum, Lactobacillus casei, and Enterococcus in kurut. We also found $L b$. helveticus, Lb. delbrueckii ssp. bulgaricus, and Strep. thermophilus in kurut from Tibet. The major reason for this difference could be ascribed to the different seasons of sample collection, the composition of yak milk, and environmental factors (Zhang et al., 2008; Sun et al., 2010).

As the major dairy product consumed daily, kurut could make a beneficial contribution to the health of local people as a large number of LAB are ingested 
Table 2. Restriction fragment length polymorphism types of $16 \mathrm{~S}$ rRNA gene sequences from the clone library, listed with phylogenetic affiliation, accession number of representative clone, similarity (NCBI), and percentage similarity

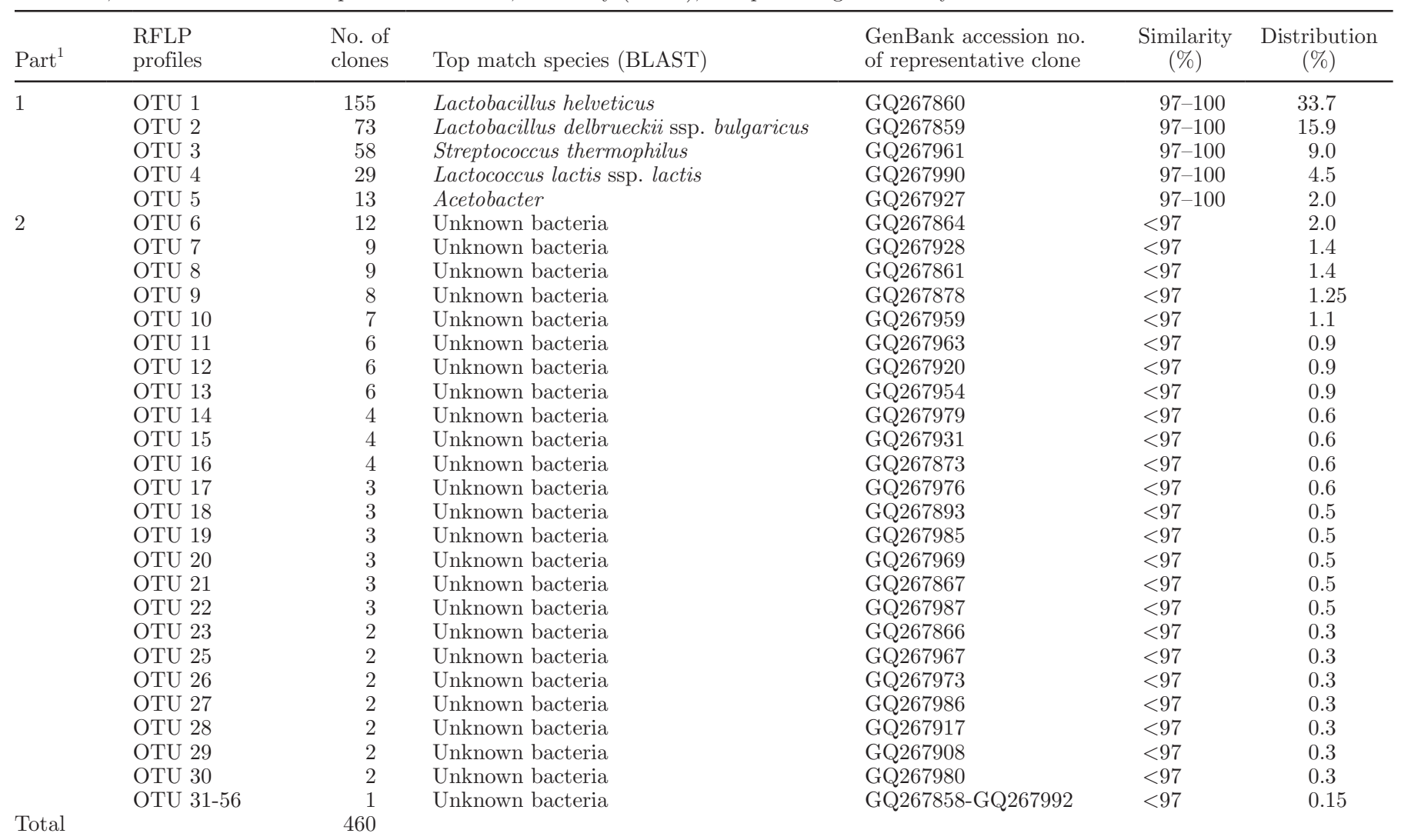

${ }^{1}$ Part 1 includes operational taxonomic units (OTU) with high similarity to sequences in GenBank (OTU 1 to OTU 5); part 2 includes those with low similarity (OTU 6 to OTU 56).

simultaneously. Besides the health benefits, LAB play major roles in the quality of fermented dairy products, such as the key flavor, texture, and preservative qualities (Atrih et al., 2001; Messens and Vuyst, 2002; Ahmad and Irene, 2007). Streptococcus thermophilus is an industrially important species used in the production of fermented dairy products, and its main industrial roles are the production of lactic acid and the formation of texture and flavor during cheese and yogurt production (Tamime and Deeth, 1980; Grappin et al., 1985). An increase in yogurt acidity during storage is often caused by strains of $L b$. delbrueckii ssp. bulgaricus, because of its acidifying activity at high acidity and low temperature (Lourens-Hattingh and Viljoen, 2001). Lactobacillus delbrueckii ssp. bulgaricus serves as the proteolytic organism in yogurt rather than Strep. thermophilus because the former has a very extensive set of proteolytic enzymes (Sieuwerts et al., 2008). In the study of contribution of LAB in flavor formation, Imhof et al. (1995) indicated a synergistic effect between $L b$. delbrueckii ssp. bulgaricus and Strep. thermophilus and underlined the important contribution of the flavor compound acetaldehyde to the resulting aroma. Lactobacillus helveticus is a lactic-acid-producing strain, which could provide the acid for yogurt formation. In addition, $L b$. helveticus could provide essential amino acids via hydrolysis of casein with its proteolytic enzymes; these proteolytic enzymes are involved in the development of flavor in fermented dairy products (Fernández et al., 1994). Therefore, it is possible that Lb. helveticus, Lb. delbrueckii ssp. bulgaricus, and Strep. thermophilus play major roles in the quality and flavor formation of kurut.

\section{Identification of Sequences with Low Phylogenetic Similarity}

The second part included phylotypes with low similarity $(<97 \%)$ to the identified species by BLAST. It is well known that high similarity $(>97 \%)$ is regarded as a threshold for species identification by $16 \mathrm{~S}$ rRNA gene (Stackebrandt and Goebel, 1994). Thus, these groups including $28.8 \%$ of the clones in the library were assigned as unknown bacteria. These sequences 


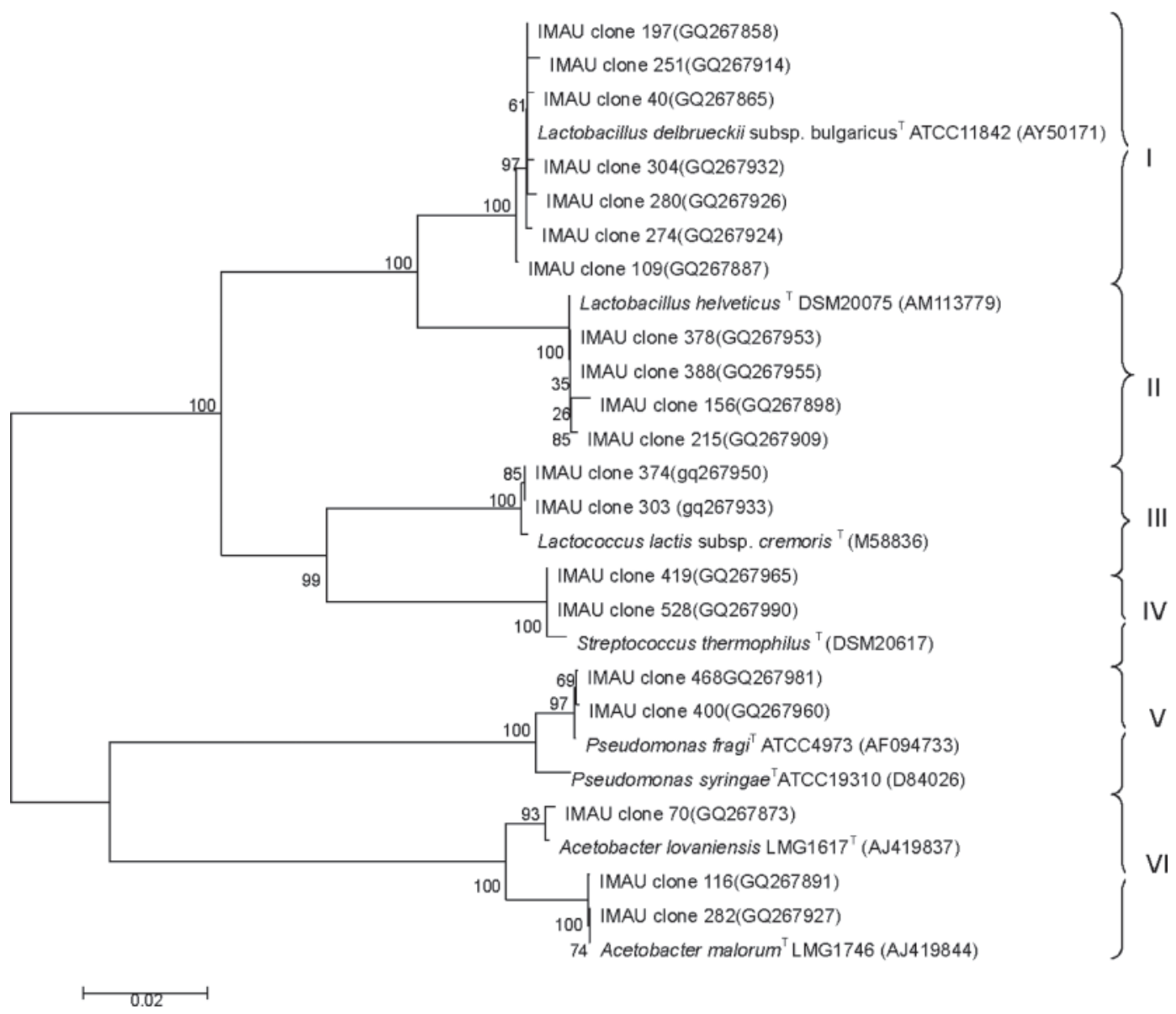

Figure 2. Phylogenetic positions of $16 \mathrm{~S}$ rRNA gene obtained in this library with high similarity to species in GenBank. IMAU clone designations refer to nomenclature from Inner Mongolia Agricultural University.

and some type strains were used to construct another phylogenetic tree (Figure 3), which was divided into 3 large clusters and 8 small ones. The 3 large clusters were cluster I, cluster II, and cluster III. Cluster I was composed of LAB and Acetobacter, whereas cluster II was composed of Pseudomonas. Cluster III contained only one clone, namely clone 421 (GQ267967), which was located in an independent branch of the phylogenetic tree and could not be identified to any species. Thus, clone 421 was regarded as an unknown species. The largest cluster was composed of 8 small groups, including Strep. thermophilus-related group (cluster i), Lactococcus cremoris-related group (cluster ii), Lactobacillus plantarum and Lactobacillus casei group (cluster iii), Lactobacillus acidophilus-related group (cluster iv), Leuconostoc mesenteroides-related group (cluster v), and Acetobacter-related group (vi). The similarity of all of these sequences to species in NCBI was $<97 \%$ by BLAST analysis. They were regarded as different groups related to the type strains in GenBank. These clones probably represented some new isolates in kurut, which could not be recovered by traditional isolation method.

Microbial composition, especially LAB and yeasts, in traditional fermented dairy products is regarded as an important topic because it plays a critical role in kurut quality formation and potential health or nutritional benefits (Zhang et al., 2008; Sun et al., 2010). However, based on previous studies, many microbes were not recovered by pure culture isolation, and consequently microbial ecology in different environmental niches was underestimated (Amann et al., 1995; Streit and Schmitz, 2004; Xu, 2006; Kennedy et al., 2008).

The occurrence of an Acetobacter-related group and a Pseudomonas-related group in kurut was noteworthy. In fact, strains of Acetobacter could not be isolated by the traditional agar plate technique, and the culture-independent method is a powerful tool for microbial composition analysis (Ongol and Asano, 2009). Acetobacter spp. can produce high amounts of acetic acid from alcohol produced by yeast present in kurut. Acetobacter spp. have a high ability to oxidize 


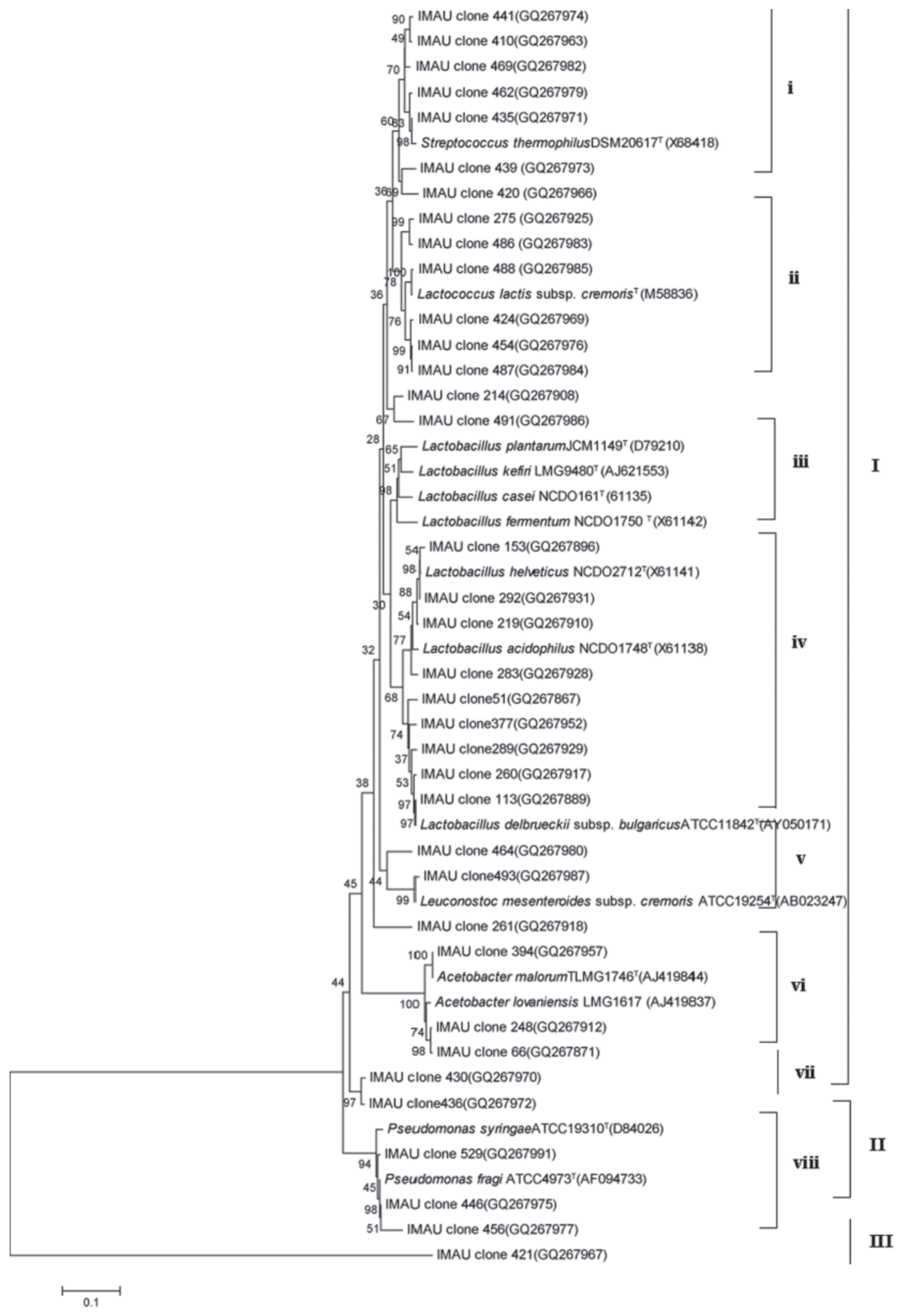

Figure 3. Phylogenetic positions of $16 \mathrm{~S}$ rRNA gene obtained in this library with low similarity to species in GenBank. IMAU clone designations refer to nomenclature from Inner Mongolia Agricultural University. 
ethanol to acetic acid, which is dependent on the enzyme alcohol dehydrogenase (Adachi et al., 1978; Yoo et al., 1994). Acetobacter is important for the quality of certain fermented dairy products with regard to flavor formation (Park et al., 2006). The pseudomonads are highly proteolytic and lipolytic, activities that accelerate the deterioration of milk products (Lengkey and Adriani, 2009). However, these strains are destroyed by pasteurization during processing of milk products. Because of the low level of bacteria in finished products, the count of pseudomonads could be underestimated by traditional plate count methods (Bedeltavana et al., 2010). In this study, the phylotype and proportion of Pseudomonas were comprehensively obtained. Interestingly, one clone (clone 421) located in the independent branch of the phylogenetic tree could not be identified to any species; therefore, we temporarily designated it as an unknown new bacterium in kurut, which should be further studied in single pure culture for its physiological and biochemical characteristics and function.

\section{CONCLUSIONS}

As a geographically specific dairy food, kurut is of considerable economic and dietary importance to the local people. It shows a great diversity in fat and dry matter levels because of the different ways of processing it in different localities. Production of kurut relies heavily on its microbial composition, with different systems of proteolytic and lipolytic enzymes. In this study, most of the clones $(>70.5 \%)$ were regarded as LAB, including Lactobacillus helveticus, Lactobacillus delbrueckii ssp. bulgaricus, Streptococcus thermophilus, and Lactococcus lactis ssp. lactis. The results generally agreed with previous literature. Interestingly, we also detected sequences of the genera Acetobacter and Pseudomonas in kurut. Furthermore, some sequences of unknown bacteria in the kurut found in this study were novel and not mentioned in previous reports. Our results may be valuable for quality improvement and industrial production of kurut in the future. To provide a better understanding of microbial ecology in kurut, the application of traditional culture method combined with molecular biology technology would be very useful, and future studies on microbial diversity in traditional fermented dairy products should employ both culturedependent and culture-independent methods.

\section{ACKNOWLEDGMENTS}

This research was supported by National Natural Science Foundation of China (Grant No. 31025019), the Earmarked Fund for Modern Agro-industry Technology
Research System (Grant No. nycytx-0501), the Prophase Research Program of the 973 Project of China (Grant No. 2010CB134502), National Key Technology R\&D Program (Grant No. 2009BADC1B01), the Innovation Team Development of the Ministry of Education of China (Grant No. IRT0967), Hi-Tech Research and Development Program of China (863 Planning, Grant No.: 2011AA100901, 2011AA100902), Natural Science Foundation in Inner Mongolia of China (Grant No. 2009MS0409), Natural Science Foundation for Open Projects of Inner Mongolia (Grant No. 20102010).

\section{REFERENCES}

Adachi, O., E. Miyagawa, E. Shinagawa, K. Matsushita, and M. Ameyama. 1978. Purification and properties of particulate alcohol dehydrogenase from Acetobacter aceti. Agric. Biol. Chem. 42:2331-2340.

Ahmad, F. M., and K. P. Irene. 2007. Isolation of lactic acid bacteria from Malaysian foods and assessment of the isolates for industrial potential. Biol. Technol. 98:1380-1385.

Amann, R. I., B. J. Binder, R. J. Olson, S. W. Chisholm, R. Devereux, and D. A. Stah. 1990. Combination of 16S rRNA targeted oligonucleotide probes with flow-cytometry for analyzing mixed microbial populations. Appl. Environ. Microbiol. 56:1919-1925.

Amann, R. I., W. Ludwig, and K. H. Schleifer. 1995. Phylogenetic identification and in situ detection of individual microbial cells without cultivation. Microbiol. Rev. 59:143-169.

Aquilanti, L., S. Santarelli, G. Silvestri, A. Osimani, A. Petruzzelli, and F. Clementi. 2007. The microbial ecology of typical Italian salami during its natural fermentation. Int. J. Food Microbiol. 120:136-145.

Atrih, A., N. Rekhif, A. J. G. Moir, A. Lebrihi, and G. Lefebvre. 2001. Mode of action, purification an amino acid sequence of plantaricin C19, an anti-Listeria bacteriocin produced by Lactobacillus plantarum C19. Int. J. Food Microbiol. 68:93-104.

Bedeltavana, A., M. Haghkhah, and A. Nazer. 2010. Phenotypic characterization and PCR-ribotyping of Pseudomonas fluorescens isolates, in tracking contamination routes in the production line of pasteurized milk. Iran. J. Vet. Res. 11:222-232

Cao, Y., W. Gan, Z. Ye, H. Yu, B. Huang, and Y. Jiang. 2004. Investigation on yak milk products and their traditional process craft of Daocheng country. Pages 4-67 in Proc. Fourth Int. Congr. Yak, Research Institute of Animal Science and Veterinary Medicine of Ganzi Prefecture, Chengdu, China.

Chao, A., and T. J. Shen. 2003. Program SPADE (Species Prediction And Diversity Estimation). Program and User's Guide. Accessed Dec. 1, 2011. http://chao.stat.nthu.edu.tw/softwareCE.html.

Chen, H. C., S. Y. Wang, and M. J. Chen. 2008. Microbiological study of lactic acid bacteria in kefir grains by culture-dependent and culture-independent methods. Food Microbiol. 25:492-501.

Coppola, S., G. Blaiotta, D. Ercolini, and G. Moschetti. 2001. Molecular evaluation of microbial diversity occurring in different types of Mozzarella cheese. J. Appl. Microbiol. 90:414-420.

Delbes, C., L. Ali-Mandjee, and M. C. Montel. 2007. Monitoring bacterial communities in raw milk and cheese by culture-dependent and independent 16S rRNA gene-based analyses. Appl. Environ. Microbiol. 73:1882-1891.

Engelen, B., K. Meinken, F. von Wintzingerode, H. Heuer, H. P. Malkomes, and H. Backhaus. 1998. Monitoring impact of a pesticide treatment on bacterial soil communities by metabolic and genetic fingerprinting in addition to conventional testing procedures. Appl. Environ. Microbiol. 64:2814-2821.

Fernández, L., T. Bhowmik, and J. L. Steele. 1994. Characterization of the Lactobacillus helveticus CNRZ32 pepC gene. Appl. Environ. Microbiol. 60:333-336. 
Grappin, R., T. C. Rank, and N. F. Olson. 1985. Primary proteolysis of cheese proteins during ripening. A review. J. Dairy Sci. 68:531-540.

Handelsman, J., M. R. Rondon, S. F. Brady, J. Clardy, and R. M. Goodman. 1998. Molecular biological accesses to the chemistry of unknown soil microbes: A new frontier for natural products. Chem. Biol. 5:245-249.

Hugenholtz, P., and G. W. Tyson. 2008. Microbiology: Metagenomics. Nature 455:481-483.

Imhof, R., H. Glittli, and J. O. Bosset. 1995. Volatile organic compounds produced by thermophilic and mesophilic single strain dairy starter cultures. Lebenson. Wiss. Technol. 28:78-86.

Kemp, P. F., and J. Y. Aller. 2004. Bacterial diversity in aquatic and other environments: What $16 \mathrm{~S}$ rDNA libraries can tell us. FEMS Microbiol. Ecol. 47:161-177.

Kennedy, J., J. R. Marchesi, and A. D. Dobson. 2008. Marine metagenomics: Strategies for the discovery of novel enzymes with biotechnological applications from marine environments. Microb. Cell Fact. $7: 27$

Kumar, S., K. Tamura, and M. Nei. 2004. MEGA3: Integrated software for Molecular Evolutionary Genetics Analysis and sequence alignment. Brief. Bioinform. 5:150-163.

Lane, D. J. 1991. 16S/23S rRNA sequencing. Pages 115-175 in Nucleic Acid Techniques in Bacterial Systematics. E. Stackebrandt, and M. Goodfellow, ed. Wiley, Chichester, UK.

Lengkey, H. A. W., and L. Adriani. 2009. Uticaj mleka fermentisanog sa Lactobacillus acidophilus I Bifidobacterium spp. na sadržaj mlečne i sirćetne kiseline i Staphylococcus aureus i Pseudomonas aeruginosa. Biotechnol. Anim. Husb. 25:719-724.

Lick, S., M. Keller, W. Bockelmann, and K. J. Heller. 1996. Optimized DNA extraction method for starter cultures from yogurt. Milchwissenschaft 51:183-186.

Lourens-Hattingh, A., and B. C. Viljoen. 2001. Yogurt as probiotic carrier food. Int. Dairy J. 11:1-17.

Messens, W., and L. D. Vuyst. 2002. Inhibitory substances produced by lactobacilli isolated from sourdoughs - A review. Int. J. Food Microbiol. 72:31-43.

Obodai, M., and C. E. Dodd. 2006. Characterization of dominant microbiota of a Ghanaian fermented milk product, nyarmie, by culture- and nonculture-based methods. J. Appl. Microbiol. 100:1355-1363.

Ongol, M. P., and K. Asano. 2009. Main microorganisms involved in the fermentation of Ugandan ghee. Int. J. Food Microbiol. $133: 286-291$

Park, W., H. Zhang, B. Zhang, and L. Zhang. 2006. Mare milk. Pages 275-296 in Handbook of Milk of Non-Bovine Mammals. 1st ed. Y. W. Park, and G. F. W. Haenlein, ed. Blackwell Publishing, Oxford, UK

Pidiyar, V. J., K. Jangid, M. S. Patole, and Y. S. Shouche. 2004. Studies on cultured and uncultured microbiota of wild Culex quinquefasciatus mosquito midgut based on $16 \mathrm{~S}$ ribosomal RNA gene analysis. Am. J. Trop. Med. Hyg. 70:597-603.

Randazzo, C. L., S. Torriani, A. D. Akkermans, W. M. de Vos, and E. E. Vaughan. 2002. Diversity, dynamics, and activity of bacterial communities during production of an artisanal Sicilian cheese as evaluated by $16 \mathrm{~S}$ rRNA analysis. Appl. Environ. Microbiol. 68:1882-1892

Sambrook, J., E. F. Fritsch, and T. Maniatis. 2002. Molecular Cloning, A Laboratory Manual. 3rd ed. Cold Spring Harbor Laboratory Press, Cold Spring Harbor, NY.
Sato, H., F. Yanagida, T. Shinohara, and K. Yokotsuka. 2000. Restriction fragment length polymorphism analysis of $16 \mathrm{~S}$ rRNA genes in lactic acid bacteria isolated from red wine. J. Biosci. Bioeng. 90:335-337.

Scheirlinck, I., R. V. d. Meulen, A. V. Schoor, M. Vancanneyt, L. D. Vuyst, P. Vandamme, and G. Huys. 2008. Taxonomic structure and stability of the bacterial community in Belgian sourdough ecosystems as assessed by culture and population fingerprinting. Appl. Environ. Microbiol. 74:2414-2423.

Schloss, P. D., and J. Handelsman. 2005. Metagenomics for studying unculturable microorganisms: Cutting the Gordian knot. Genome Biol. 6:229

Sieuwerts, S., F. A. de Bok, J. Hugenholtz, and J. E. van Hylckama Vlieg. 2008. Unraveling microbial interactions in food fermentations: From classical to genomics. Appl. Environ. Microbiol. 74:4997-5007.

Stackebrandt, E., and B. M. Goebel. 1994. A place for DNA-DNA reassociation and $16 \mathrm{~S}$ rRNA sequence analysis in the present species definition in bacteriology. Int. J. Syst. Bacteriol. 44:846-849.

Streit, W. R., and R. Schmitz. 2004. Metagenomics - The key to the uncultured microbes. Curr. Opin. Microbiol. 7:492-498.

Sun, Z. H., W. J. Liu, W. Gao, M. Yang, J. C. Zhang, L. Wu, J. G. Wang, Menghebilige, T. S. Sun, and H. P. Zhang. 2010. Identification and characterization of the dominant lactic acid bacteria from kurut: The naturally fermented yak milk in Qinghai, China. J. Gen. Appl. Microbiol. 56:1-10.

Tamime, A. Y., and H. C. Deeth. 1980. Yoghurt: Technology and biochemistry. J. Dairy Prot. 43:939-977.

Temmerman, R., I. Scheirlinck, G. Huys, and J. Swings. 2003. Cultureindependent analysis of probiotic products by denaturing gradient gel electrophoresis. Appl. Environ. Microbiol. 69:220-226.

Wang, J., X. Chen, W. Liu, M. Yang, A. Caicike, and H. Zhang. 2008 Identification of Lactobacillus from koumiss by conventional and molecular methods. Eur. Food Res. Technol. 227:1555-1561.

Ward, D. M., R. Weller, and M. M. Bateson. 1990. 16S rRNA sequences reveal numerous uncultured microorganisms in a natural community. Nature 345:63-65.

Weidler, G. W., M. Dornmayr-Pfaffenhuemer, F. W. Gerbl, W. Heinen, and H. Stan-Lotter. 2007. Communities of archaea and bacteria in a subsurface radioactive thermal spring in the Austrian Central Alps, and evidence of ammonia-oxidizing Crenarchaeota Appl. Environ. Microbiol. 73:259-270.

Xu, J. P. 2006. Microbial ecology in the age of genomics and metagenomics: Concepts, tools, and recent advances. Mol. Ecol. 15:17131731.

Yanagida, F., Y. Chen, and M. Yasaki. 2007. Isolation and characterization of lactic acid bacteria from lakes. J. Basic Microbiol. $47: 184-190$

Yoo, J. C., J. B. Sim, H. K. Kim, H. S. Chun, and S. J. Kim. 1994 Purification and properties of membrane-bound alcohol dehydrogenas from Acetobacter sp. HA. Korean J. Microbiol. 32:78-83.

Yu, J., Z. Sun, W. Liu, J. Zhang, T. Sun, Q. Bao, and H. Zhang, 2009. Rapid identification of lactic acid bacteria isolated from home-made fermented milk in Tibet. J. Gen. Appl. Microbiol. $55: 181-190$

Zhang, H., J. Xu, J. Wang, Menghebilige, T. Sun, H. Li, and M. Guo. 2008. A survey on chemical and microbiological composition of kurut, naturally fermented yak milk from Qinghai in China. Food Contr. 19:578-586. 